\title{
Some Important Food Quality Traits of Autochthonous Grape Cultivars
}

\author{
Muhammed Kupe, ${ }^{1}$ Sezai Ercisli, ${ }^{1}$ Neva Karatas, ${ }^{2}$ Sona Skrovankova $\mathbb{D}^{3},{ }^{3}$ Jiri Mlcek (D), \\ Monika Ondrasova, ${ }^{3}$ and Lukas Snopek (iD) \\ ${ }^{1}$ Department of Horticulture, Ataturk University, Faculty of Agriculture, Erzurum 25240, Turkey \\ ${ }^{2}$ Department of Nutrition and Dietetics, Ataturk University, Faculty of Health Sciences, Erzurum 25240, Turkey \\ ${ }^{3}$ Department of Food Analysis and Chemistry, Tomas Bata University in Zlin, Faculty of Technology, Zlin 76001, Czech Republic \\ ${ }^{4}$ Department of Environmental Security, Tomas Bata University in Zlin, Faculty of Logistics and Crisis Management, \\ Uherske Hradiste 68601, Czech Republic
}

Correspondence should be addressed to Jiri Mlcek; mlcek@utb.cz

Received 9 March 2021; Accepted 26 October 2021; Published 16 November 2021

Academic Editor: Alessandra Durazzo

Copyright (c) 2021 Muhammed Kupe et al. This is an open access article distributed under the Creative Commons Attribution License, which permits unrestricted use, distribution, and reproduction in any medium, provided the original work is properly cited.

\begin{abstract}
Grapes (Vitis L.), one of the most important and old fruit crops in the world, are grown in a wide range of environments from Australia to North America and from Japan to Chile. All grape growing countries use both international and local cultivars in production to obtain fresh and dried fruits or wine. In Turkey, each region has their own local grape cultivars. Seven local cultivars and one standard grape cultivar, grown in Coruh valley, were analyzed for morphological traits (bunch size, berry color, and berry shape), biochemical characteristics (sugars, organic acids, vitamin C, phenolic compounds, total carotenoids, and flavonoids content), and \% inhibition level (antioxidant capacity). The grape cultivars differed from each other in the morphological and biochemical traits. The grape berries contain predominantly nine main phenolic compounds, five organic acids, and two sugars. Among phenolic compounds, chlorogenic acid, syringic acid, rutin, and quercetin were found to be dominant for most of the cultivars between $2.365-5.112 \mathrm{mg} / \mathrm{L}, 0.923-2.147 \mathrm{mg} / \mathrm{L}, 0.856-1.711 \mathrm{mg} / \mathrm{L}$, and $0.621-1.347 \mathrm{mg} / \mathrm{L}$, respectively. The local cultivar Kirmizi Istanbul had more chlorogenic acid than the other cultivars. The berries with darker skin color, specifically Kara Turfanda and Nanebur, had higher \% inhibition level (antioxidant capacity) than the brighter ones, which correspond also to the results of flavonoid contents. Overall, the local genotypes were found promising due to favorable properties and could be recommended for farmers and consumers.
\end{abstract}

\section{Introduction}

Turkey has rich flora due to diverse topography and geomorphology conditions. The country includes 3 out of the world's 34 biodiversity hotspots, namely, Caucasus, the Mediterranean, and the Irano-Anatolian [1-4]. One of the hotspots for plant biodiversity in the country is Coruh valley.

The Vitis genus is widely distributed in the world, and so far, 80 Vitis species are identified [5]. The Vitis genus has two subgenera: Muscadinia and Euvitis. Muscadines (V. rotundifolia Michx.) is native to America and cultivated in the southeastern US $[6,7]$. The Euvitis subgenus including the most cultivated grapevines is divided into three groups: the American group, the East Asia group, and the Eurasian group. Most of the Vitis cultivars grown in the world belong to $V$. vinifera within the Eurasian group. $V$. vinifera has two subspecies (vinifera and sylvestris), and $V$. vinifera sylvestris corresponds to the wild form of the vine, and vinifera, referring to the cultivated form $[8,9]$.

Turkey, located between Asia and Europe, is important for grape cultivation. Viticulture has spread to almost all geographical regions in the country, and, in particular, local grape cultivars were found along the ancient Silk Road $[10,11]$. Old civilizations belonging to different religious settlers in Anatolia 
played an important role in expanding grape cultivation in Turkey $[12,13]$. Many local grape cultivars found in Anatolia and currently over 1000 grape local cultivars exist in the country [3]. These local cultivars could be important in grape breeding in Turkey due to their rich morphological variation [10]. In addition, local cultivars are widely used in different parts of country and make a significant economical contribution [13]. More recently, local cultivars under pressure of international well-known cultivars and international cultivars began to replace domestic cultivars [14].

To avoid genetic erosion of local grapes, it is important to characterize of them. This local germplasm could be important to obtain new grape cultivars with higher yield and better berry characteristics [14-16].

The grape berries have been reported to be rich in phenolic compounds, organic acids, and specific sugars, which contribute to organoleptic properties [17, 18]. Berry organoleptic properties of grapes are mostly determined by organic acids and sugars and both influence flavor, taste, color, and aroma of berries [19].

Grape cultivars can be characterized by morphological, biochemical, and molecular markers [7, 20-22]. The evaluation of grape berry characteristics by morphological and molecular markers supplements the biochemical classification, and the preservation of local and less known grape cultivars is an important task. The biochemical marker technique is a powerful tool for the characterization in particular diverse grape germplasm and has been widely used in various analyses of grape cultivars and the identification of germplasm in different parts of the world [23, 24].

However, only limited works have been published concerning local grape cultivars analyzed using biochemical markers in particular Northeastern Turkey. By determining and evaluating the biochemical differences of local grape cultivars grown in collection vineyard Yusufeli district located in Northeastern Turkey, an attempt has been made to upgrade the database of biochemical potential of individual local grape cultivar, as it is reasonable to maintain genetic variability in Turkey and, in doing so, also retain specific characteristics of some older and less known historical grape cultivars.

\section{Material and Methods}

2.1. Plant Material. In this study, seven local grape cultivars (Artvin, Beyaz Istanbul, Kirmizi Istanbul, Kara Turfanda, Kutuk, Nanebur, and Razaki) and one standard national cultivar (Razaki) were used to determine their morphological and biochemical characteristics. At the full maturation stage, around three $\mathrm{kg}$ of bunches was harvested from each cultivar in 2019. The grape samples were stored at $-80^{\circ} \mathrm{C}$ until their laboratory biochemical analyses. As morphological traits, average bunch size, berry color, berry shape, and consumption type were determined immediately after harvest [3].

2.2. Analysis of Phenolic Compounds. For phenolic compound analysis, the HPLC method developed by RodriguezDelgado et al. [25] was used. Firstly, samples were distilled with water in 1:1 ratio and centrifuged at $15000 \mathrm{rpm}$ for $15 \mathrm{~min}$. The obtained supernatant was filtered $(0.45 \mu \mathrm{m}$ millipore filters) and then injected to HPLC. DAD detector was used for chromatographic separation (Agilent. USA), and ODS column (HiChrom, USA) in Agilent 1100 (Agilent) was used. As mobile phase, two solvents, namely, Solvent A methanol-acidic acid-water $(10: 2: 88)$ and Solvent B methanol-acidic acid-water $(90: 2: 8)$, were used. The separation was conducted at 254 and $280 \mathrm{~nm}$, and the flow rate was determined as $1 \mathrm{~mL} / \mathrm{min}$, and the injection volume was determined as $20 \mu \mathrm{L}$. The method of Sasmaz et al. [26] was used for quantification of phenolic compounds.

2.3. Analysis of Organic Acids. The method of Bevilacqua and Califano [27] was used for organic acid extraction. $5 \mathrm{~g}$ of berry samples was placed to centrifuge tubes and homogenized by adding $20 \mathrm{ml} 0.009 \mathrm{NH}_{2} \mathrm{SO}_{4}$ (Heidolph Silent Crusher $M$, Germany). After that, it was mixed on the rotary agitator (Heidolph Unimax 1010, Germany) for 1 hour and centrifuged at $15000 \mathrm{rpm}$ for 15 minutes. The aqueous part was filtered with $0.45 \mu \mathrm{m}$ membrane filter (Millipore MillexHV Hydrophilic PVDF, Millipore, USA) two times and, finally, with SEP-PAK $\mathrm{C}_{18}$ cartridge. HPLC device (Agilent HPLC 1100 series G 1322 A, Germany) was used for organic acid analysis with Aminex HPX - $87 \mathrm{H}, 300 \mathrm{~mm} \times 7.8 \mathrm{~mm}$ column (Bio-Rad Laboratories, Richmond, CA, USA). DAD detector in the system (Agilent, USA) was set at 214 and $280 \mathrm{~nm}$ wavelengths. Results are expressed as $\mathrm{g} / \mathrm{l}$.

2.4. Analysis of Sugars. The method of Melgarejo et al. [28] was used for analysis of sugars. For this, $5 \mathrm{~g}$ fruit sample was homogenized and centrifuged at $12000 \mathrm{rpm}$ for $2 \mathrm{~min}$, after which it is run in SEP-PAK C18 column. The extract was preserved at $-20^{\circ} \mathrm{C}$ until analysis. The filtered sugars from the samples were determined using $\mu$ Bondapak- $\mathrm{NH}_{2}$ column with $85 \%$ acetonitrile liquid phase in HPLC.

2.5. Analysis of Vitamin C (Ascorbic Acid). Five g of whole fruits was placed to test tubes, and then $5 \mathrm{ml} 2.5 \%$ M-phosphoric acid solution was poured on it. The mixture was centrifuged at $6500 \mathrm{rpm}$ for $10 \mathrm{~min}$ at $4^{\circ} \mathrm{C}$. $0.5 \mathrm{ml}$ was taken, and $2.5 \% \mathrm{M}$-phosphoric solution was added until reaching $10 \mathrm{ml}$. The mixture was filtered by $0.45 \mu \mathrm{m}$ Teflon filter and injected to HPLC. Ascorbic acid was detected by the C18 column (Phenomenex Luna C18, $250 \times 4.60 \mathrm{~mm}$ ) in the HPLC. Water was used as a mobile phase with $1 \mathrm{ml} / \mathrm{min}$ flow rate and $\mathrm{pH}$ of 2.2 adjusted with $\mathrm{H}_{2} \mathrm{SO}_{4}$. The DAD detector with $254 \mathrm{~nm}$ wavelength was used for the readings [29].

2.6. Analysis of Total Carotenoids. Carotenoids were extracted by the method described by Sass-Kiss et al. [30]. Briefly, about $5 \mathrm{~g}$ of homogenized grape berry samples was weighted and placed in $100 \mathrm{~mL}$ flask and extracted in dark with $50 \mathrm{~mL} n$-hexane:acetone:ethanol (2:1:1). After stirring for $30 \mathrm{~min}$, the upper phase was recovered. $10 \mathrm{~mL}$ of $n$ hexane was added for a second extract. The mixture of the 
two $n$-hexane phases was used for the determination of total carotenoids by spectrophotometry at $420 \mathrm{~nm}$. Concentrations of carotenoids are estimated by reference to the calibration curve using $\beta$-carotene as standard, and the results are expressed as $\mu \mathrm{g} / \mathrm{g}$ of fresh weight $(\mu \mathrm{g} / \mathrm{g}$ FW).

2.7. Analysis of Total Flavonoids. Total flavonoids were measured by a colorimetric assay developed by Kim et al. [31] with modifications. Briefly, $0.5 \mathrm{~mL}$ of test samples' solution in methanol $(5 \mathrm{mg} / 100 \mathrm{~mL})$ was mixed with $2 \mathrm{~mL}$ of distilled water and $150 \mu \mathrm{l}$ of sodium nitrate. After $6 \mathrm{~min}$, $150 \mu \mathrm{l}$ of $10 \%$ aluminum chloride and $2 \mathrm{~mL}$ of $1 \mathrm{M}$ sodium hydroxide were added and left at room temperature for $15 \mathrm{~min}$. Absorbance of the mixtures was measured at $510 \mathrm{~nm}$ (UV-Visible Ultraspec 2000 spectrophotometer, England), and total flavonoid contents were expressed as catechin equivalents (mg CE/g FW).

2.8. DPPH Free Radical Scavenging Activity. The radical scavenging activity of grape extracts was measured by the $\mathrm{DPPH}$ assay. This activity was measured according to the previously described method of Anastasiadi et al. [32]. Briefly, $100 \mu \mathrm{M}$ solution of DPPH was prepared in methanol, and $2.7 \mathrm{~mL}$ of this solution was added to $0.3 \mathrm{~mL}$ of the grape extract solution in methanol at the same concentration $(0.1 \mathrm{mg} / \mathrm{mL})$. After $10 \mathrm{~min}$, the absorbance was measured at $517 \mathrm{~nm}$. The radical scavenging activity was calculated as a percentage of $\mathrm{DPPH}$ discoloration using the following equation:

$$
\text { DPPH radical scavenging } \%=\left[\left(\frac{A_{0}-A_{1}}{A_{0}}\right) \times 100\right] \text {, }
$$

where $A_{0}$ is the absorbance of the DPPH solution and $A_{1}$ is the absorbance of the sample.

2.9. Statistical Analysis. In the statistical evaluations, Windows SPSS 20 was used, and the differences between the means were evaluated by subjecting to ANOVA variance analysis and determined with Duncan multiple comparison test $(p<0.005)$.

\section{Results and Discussion}

3.1. Morphological Traits. The results of morphological characteristics of eight autochthonous grape cultivars are shown in Table 1. The local cultivars exhibited a great diversity of bunch size, berry color, and berry shape.

Beyaz Istanbul and Kirmizi Istanbul cultivars had the biggest bunch size; Artvin and Kara Turfanda cultivars had medium bunch size; and Kutuk, Nanebur, and Razaki had small bunch size. Because the Beyaz Istanbul and Kirmizi Istanbul cultivars had longer bunches compared to the other cultivars, they could be considered better for cultivation. This is an important characteristic since berries have the opportunity for expansion, thereby increasing in size and weight. Short bunches tend to have compacted berries, which reduce berry expansion, thereby leading to smaller/ narrow berries as exhibited by Sauvignon Blanc and Chenin Blanc.

Four cultivars had the brightest skin color (green-yellow berry color): Artvin, Beyaz Istanbul, Kutuk, and Tokat, and Kirmizi Istanbul cultivar had rose skin color. Kara Turfanda and Nanebur (blue-black) had the darkest skin color, and Razaki (blue-dark red) had berry skin color. The majority of studied cultivars was found suitable for table consumption. As Kuria et al. [7] found, the red rose berry skin color, greenyellow color, and blue-black color are as a result of different composition and amount of phenolic compounds within the grape skin. Grape skin color is influenced by the presence of anthocyanin; therefore, it could affect the quality of juice, wine, and also the market value of table grapes [33].

Artvin, Kirmizi Istanbul, Kutuk, and Razaki cultivars are characterized by oval berry shape, Beyaz Istanbul and Nanebur had ellipsoid berry shape, and Kara Turfanda and Tokat had round berry shape. All the cultivars had uniform size of berries to make these local cultivars suitable for commercialization. Salimov et al. [22] state that berry uniformity is among the most important factors that influence the trade appearance of grapes.

3.2. Phenolic Compounds. The content of major and minor phenolic compounds of autochthonous grape cultivars is shown in Tables 2 and 3. There were statistically significant differences $(p<0.05)$ among grape cultivars for both major and minor phenolic compounds, except ferulic acid amount (Table 2).

Chlorogenic acid and syringic acid from the phenolic acids group and rutin and quercetin from flavonoids were found to be in higher amount than others in eight analyzed grape cultivars (Table 2). Among them, chlorogenic acid was the most abundant with the concentration interval 2.365-5.112 mg/L, while Kirmizi Istanbul and Artvin had the highest values, and Nanebur the lowest one, approximately twice the difference between cultivars. The second most abundant phenolic compound is syringic acid (0.923-2.147 mg/L), which had the highest value for $\mathrm{cv}$. Nanebur and Artvin had the lowest value for cv. Kara Turfanda had more than twice the difference between cultivars. Rutin and quercetin content were in the range of $0.856-1.711 \mathrm{mg} / \mathrm{L}$ and $0.621-1.347 \mathrm{mg} / \mathrm{L}$, respectively. Better cultivars with higher content of these two components were found to be Nanebur and Tokat.

Grape is one of the well-known horticulture plants that include many phenolic compounds. Phenolic compounds of grape berries are the third most abundant group, after sugars and organic acids [3]. Other studies [3, 34, 35] also indicated that grape berries belonging to different cultivars contain mostly chlorogenic acid, rutin, quercetin, syringic acid, $p$ coumaric acid, and catechin. Phenolic compounds are well known to contribute not only to organoleptic quality as color, astringency, and bitterness, but also to health benefits of berries. They can be used as biochemical markers for authenticity of local cultivars as well [3].

As indicated in Table 3, to the minor components belong the catechin, $o$-coumaric acid, gallic acid, vanillic acid, and 
TABLE 1: Some important morphological characteristics of grape cultivars.

\begin{tabular}{lcccc}
\hline Cultivar & Bunch size & Berry color & Berry shape & Consumption type \\
\hline Artvin & Medium & Green-yellow & Ovate & Table \\
Beyaz Istanbul & High & Green-yellow & Ellipsoid & Juice \\
Kirmizi Istanbul & High & Rose & Ovate & Table \\
Kara Turfanda & Medium & Blue-black & Oound & Table \\
Kutuk & Low & Green-yellow & Ellipsoid & Table \\
Nanebur & Low & Blue-black & Round & Table \\
Tokat & High & Green-yellow & Table \\
Razaki & Low & Blue-dark red & Ovate & Table \\
\hline
\end{tabular}

TABLE 2: Major phenolic compounds in berries of grape cultivars (mg/l).

\begin{tabular}{lcccc}
\hline Cultivar & Chlorogenic acid & Syringic acid & Rutin & Quercetin \\
\hline Artvin & $4.667 \pm 0.27 \mathrm{~b}$ & $1.665 \pm 0.09 \mathrm{~b}$ & $1.244 \pm 0.06 \mathrm{bc}$ & $0.887 \pm 0.02 \mathrm{de}$ \\
Beyaz Istanbul & $2.967 \pm 0.21 \mathrm{e}$ & $1.404 \pm 0.11 \mathrm{bc}$ & $1.115 \pm 0.05 \mathrm{c}$ & $1.210 \pm 0.03 \mathrm{~b}$ \\
Kirmizi Istanbul & $5.112 \pm 0.18 \mathrm{a}$ & $1.210 \pm 0.07 \mathrm{c}$ & $0.856 \pm 0.06 \mathrm{~d}$ & $1.011 \pm 0.02 \mathrm{c}$ \\
Kara Turfanda & $3.549 \pm 0.23 \mathrm{de}$ & $0.923 \pm 0.12 \mathrm{~d}$ & $0.967 \pm 0.02 \mathrm{~cd}$ & $0.904 \pm 0.03 \mathrm{~d}$ \\
Kutuk & $3.661 \pm 0.14 \mathrm{~d}$ & $1.256 \pm 0.05 \mathrm{bc}$ & $1.532 \pm 0.03 \mathrm{ab}$ & $0.621 \pm 0.01 \mathrm{~g}$ \\
Nanebur & $2.365 \pm 0.10 \mathrm{f}$ & $2.147 \pm 0.09 \mathrm{a}$ & $1.711 \pm 0.04 \mathrm{a}$ & $1.188 \pm 0.04 \mathrm{bc}$ \\
Tokat & $3.823 \pm 0.10 \mathrm{~cd}$ & $1.369 \pm 0.07 \mathrm{bc}$ & $1.056 \pm 0.04 \mathrm{~cd}$ & $1.347 \pm 0.04 \mathrm{a}$ \\
Razaki & $4.119 \pm 0.13 \mathrm{c}$ & $0.986 \pm 0.10 \mathrm{~cd}$ & $1.424 \pm 0.07 \mathrm{~b}$ & $0.774 \pm 0.03 \mathrm{f}$ \\
\hline
\end{tabular}

Different letters in the same column indicate statistically significant differences $(p<0.05)$.

TABLE 3: Minor phenolic compounds in berries of grape cultivars (mg/l).

\begin{tabular}{lccccc}
\hline Cultivar & Catechin & $o$-Coumaric acid & Gallic acid & Vanillic acid & Ferulic acid \\
\hline Artvin & $0.566 \pm 0.02 \mathrm{~cd}$ & $0.711 \pm 0.02 \mathrm{a}$ & $0.190 \pm 0.01 \mathrm{c}$ & $0.240 \pm 0.01 \mathrm{a}$ & $0.081 \pm 0.01^{\mathrm{NS}}$ \\
Beyaz Istanbul & $0.911 \pm 0.05 \mathrm{ab}$ & $0.774 \pm 0.03 \mathrm{a}$ & $0.213 \pm 0.01 \mathrm{bc}$ & $0.144 \pm 0.02 \mathrm{~b}$ & $0.046 \pm 0.01$ \\
Kirmizi Istanbul & $0.403 \pm 0.03 \mathrm{~d}$ & $0.678 \pm 0.03 \mathrm{ab}$ & $0.355 \pm 0.02 \mathrm{ab}$ & $0.215 \pm 0.01 \mathrm{ab}$ & $0.054 \pm 0.01$ \\
Kara Turfanda & $0.580 \pm 0.02 \mathrm{c}$ & $0.456 \pm 0.02 \mathrm{~cd}$ & $0.387 \pm 0.02 \mathrm{a}$ & $0.112 \pm 0.02 \mathrm{~b}$ & $0.072 \pm 0.01$ \\
Kutuk & $0.783 \pm 0.02 \mathrm{~b}$ & $0.380 \pm 0.01 \mathrm{c}$ & $0.288 \pm 0.01 \mathrm{~b}$ & $0.203 \pm 0.01 \mathrm{ab}$ & $0.045 \pm 0.01$ \\
Nanebur & $0.646 \pm 0.03 \mathrm{bc}$ & $0.540 \pm 0.03 \mathrm{ab}$ & $0.240 \pm 0.01 \mathrm{bc}$ & $0.186 \pm 0.01 \mathrm{ab}$ & $0.025 \pm 0.01$ \\
Tokat & $0.966 \pm 0.05 \mathrm{a}$ & $0.572 \pm 0.03 \mathrm{ab}$ & $0.225 \pm 0.01 \mathrm{bc}$ & $0.135 \pm 0.01 \mathrm{~b}$ & $0.062 \pm 0.01$ \\
Razaki & $0.835 \pm 0.04 \mathrm{ab}$ & $0.590 \pm 0.02 \mathrm{~b}$ & $0.303 \pm 0.02 \mathrm{ab}$ & $0.177 \pm 0.02 \mathrm{ab}$ & $0.036 \pm 0.01$ \\
\hline
\end{tabular}

Different letters in the same column indicate statistically significant differences $(p<0.05)$.

ferulic acid. Among them, the contents of catechin and $o$ coumaric acid were higher for most of the analyzed cultivars than the amount of the other minor phenolic compounds. Catechin and $o$-coumaric acid concentration of eight grape cultivars varied from 0.403 to $0.966 \mathrm{mg} / \mathrm{L}$ and from 0.380 to $0.774 \mathrm{mg} / \mathrm{L}$, respectively. Better cultivars with higher content of these components were found to be Beyaz Istanbul and Tokat cultivars. For gallic acid and vanillic acid of grape cultivars, their content was from 0.190 (cv. Artvin) to $0.387 \mathrm{mg} / \mathrm{L}$ and 0.112 (cv. Kara Turfanda) to $0.240 \mathrm{mg} / \mathrm{L}$, respectively. The ferulic acid content was the lowest and ranged from $0.025 \mathrm{mg} / \mathrm{L}$ (cv. Nanebur) to $0.081 \mathrm{mg} / \mathrm{L}$, respectively.

3.3. Organic Acids. The content of individual organic acids of eight grape cultivars is shown in Table 4. The genotypes contain tartaric acid, malic acid, succinic acid, citric acid, and fumaric acid in its berries. Cultivars statistically differ from each other in terms of individual organic acid content $(p<0.05)$.
The amount of organic acids in our study was in this descending order: tartaric acid $>$ malic acid $>$ citric acid$>$ succinic acid $>$ fumaric acid. Previous studies [36, 37] also indicated that tartaric and malic acid represent more than $80 \%$ of all organic acids found in grapes. Tartaric and malic acid contents were in the range of $2.114-5.114 \mathrm{~g} / \mathrm{L}$ and $1.320-3.540 \mathrm{~g} / \mathrm{L}$, respectively. Cultivars with high content of these acids were Kara Turfanda and Kutuk; the lowest acids were assessed for Artvin cultivar. Citric, succinic, and fumaric acid contents of grape cultivars were found to be in the ranges $0.210-0.844 \mathrm{~g} / \mathrm{L}, \quad 0.260-0.607 \mathrm{~g} / \mathrm{L}$, and $0.015-0.083 \mathrm{~g} / \mathrm{L}$, respectively.

Previous studies revealed that grape cultivars, sampled from different parts of the world, are rich for tartaric acid, followed by malic acid [3, 38-40]. Sabir et al. [39] reported tartaric acid content of five Turkey grape cultivars in the range $3.8-5.2 \mathrm{~g} / \mathrm{L}$, malic acid in the range $2.8-3.6 \mathrm{~g} / \mathrm{L}$, and citric acid in the range $0.200-0.400 \mathrm{~g} / \mathrm{L}$ indicating similarities with our study. Guler and Candemir [41] reported that 24 grape cultivar juices had tartaric acid between 0.53 and $13.16 \mathrm{~g} / 100 \mathrm{~g}$ and malic acid in the range $1.21-43.96 \mathrm{~g} / 100 \mathrm{~g}$. 
TABLE 4: Organic acid content in berries of grape cultivars (g/l).

\begin{tabular}{lccccc}
\hline Cultivar & Tartaric & Malic & Citric & Succinic & Fumaric \\
\hline Artvin & $2.114 \pm 0.07 \mathrm{f}$ & $1.320 \pm 0.05 \mathrm{e}$ & $0.844 \pm 0.05 \mathrm{a}$ & $0.545 \pm 0.03 \mathrm{ab}$ & $0.024 \pm 0.01^{\mathrm{NS}}$ \\
Beyaz Istanbul & $3.886 \pm 0.10 \mathrm{c}$ & $2.155 \pm 0.05 \mathrm{~cd}$ & $0.775 \pm 0.04 \mathrm{ab}$ & $0.532 \pm 0.05 \mathrm{ab}$ & $0.018 \pm 0.01$ \\
Kirmizi Istanbul & $2.960 \pm 0.08 \mathrm{e}$ & $1.720 \pm 0.02 \mathrm{~d}$ & $0.715 \pm 0.04 \mathrm{~b}$ & $0.368 \pm 0.03 \mathrm{ab}$ & $0.045 \pm 0.01$ \\
Kara Turfanda & $5.114 \pm 0.11 \mathrm{a}$ & $2.330 \pm 0.03 \mathrm{c}$ & $0.255 \pm 0.03 \mathrm{de}$ & $0.260 \pm 0.04 \mathrm{~b}$ & $0.083 \pm 0.02$ \\
Kutuk & $4.120 \pm 0.04 \mathrm{bc}$ & $3.540 \pm 0.04 \mathrm{a}$ & $0.330 \pm 0.04 \mathrm{~d}$ & $0.300 \pm 0.05 \mathrm{~b}$ & $0.035 \pm 0.02$ \\
Nanebur & $2.870 \pm 0.03 \mathrm{e}$ & $1.402 \pm 0.04 \mathrm{de}$ & $0.650 \pm 0.03 \mathrm{c}$ & $0.505 \pm 0.03 \mathrm{ab}$ & $0.015 \pm 0.01$ \\
Tokat & $3.450 \pm 0.04 \mathrm{~d}$ & $2.115 \pm 0.05 \mathrm{~cd}$ & $0.805 \pm 0.05 \mathrm{a}$ & $0.607 \pm 0.03 \mathrm{a}$ & $0.030 \pm 0.01$ \\
Razaki & $4.450 \pm 0.06 \mathrm{~b}$ & $2.956 \pm 0.03 \mathrm{~b}$ & $0.210 \pm 0.03 \mathrm{e}$ & $0.308 \pm 0.02 \mathrm{ab}$ & $0.042 \pm 0.02$ \\
\hline
\end{tabular}

Different letters in the same column indicate statistically significant differences $(p<0.05)$.

Soyer et al. [42] investigated organic acid composition in grapes and grape juices of 11 different grape Turkey varieties, and for tartaric, malic, and citric acids, reported values were $4.98-7.48 \mathrm{~g} / \mathrm{L}, 1.43-3.40 \mathrm{~g} / \mathrm{L}$, and $30-164 \mathrm{mg} / \mathrm{L}$, respectively, which is close to our values. Lima et al. [43] found, in five new Brazilian grape cultivars ( $V$. labrusca L.), that the amount of tartaric and malic acids was in the ranges $4.60-6.32 \mathrm{~g} / \mathrm{L}$ and $2.12-4.15 \mathrm{~g} / \mathrm{L}$, respectively. In another study, Coelho et al. [44] reported tartaric acid in the range $4.02-5.38 \mathrm{~g} / \mathrm{L}$.

3.4. Vitamin $C$ and Sugars. Data related to ascorbic acid (vitamin C) and individual sugar (glucose, fructose, and sucrose) concentrations of eight grape cultivars are presented in Table 5.

As shown in Table 5 , there were statistically significant differences for ascorbic acid amounts among cultivars at $p<0.05$ level. The grape cultivars in this study exhibited ascorbic acid concentrations between 15.17 and (Kirmizi Istanbul) and $30.18 \mathrm{mg} / 100 \mathrm{~g}$ (Nanebur). This indicates that vitamin $\mathrm{C}$ was quite variable among the used autochthonous grape cultivars. A similar variation of vitamin $\mathrm{C}$ among autochthonous grape cultivars grown in eastern Anatolia has been reported by Eyduran et al. [3], with the content being between 11.21 and $33.55 \mathrm{mg} / 100 \mathrm{~g}$. Algerian varieties studied by Derradj-Benmeziane et al. [45] were reported in vitamin $\mathrm{C}$ in the range of 12.33 (cv. Victoria) to $30.80 \mathrm{mg} / 100 \mathrm{ml}$ (cv. Gros Noir). In the USA grape cultivars, vitamin C content varied between 27.7 and $40.0 \mathrm{mg} / 100 \mathrm{ml}$ [46]. The results of the above studies are in good agreement with our findings. Preharvest circumstances such as climatic conditions, farming practices, and maturity at harvest and postharvest conditions such as storage strongly influence vitamin C content in horticulture crops. Species, cultivars, genotypes, accessions, etc. are also responsible for the wide variation of vitamin C content in horticulture crops [47].

Glucose and fructose contents were found quite variable among grape cultivars, and there were statistically significant differences, while sucrose content indicated non-statistically-significant differences among cultivars (Table 5). Considering all cultivars, the glucose content was found to be higher than the fructose concentration, and these sugars were predominant. Sucrose was indicated in a much lower amount in the analyzed grape samples.

The glucose amount of the cultivars was in the descending order Nanebur $(14.17 \mathrm{~g} / 100 \mathrm{~g})$
$>$ Razaki $>$ Kirmizi Istanbul $>$ Kutuk $>$ Beyaz Istanbul $>$ Kara Turfanda $>$ Tokat $>$ Artvin $(7.10 \mathrm{~g} / 100 \mathrm{~g})$, respectively. Kirmizi Istanbul cultivar had the highest fructose content $(8.44 \mathrm{~g} / 100 \mathrm{~g})$, followed by Razaki and Nanebur, which indicate that these three cultivars are the sweetest (glucose and fructose content) compared to the analyzed cultivars. Tokat and Artvin cultivars belong to the least sweet. The sucrose content was detected in low values; they varied from 0.47 to $0.95 \mathrm{~g} / 100 \mathrm{~g}$. Eyduran et al. [3] reported glucose and fructose concentrations in the ranges of $9.51-16.47 \mathrm{~g} / 100 \mathrm{~g}$ and 8.03 to $15.55 \mathrm{~g} / 100 \mathrm{~g}$, respectively, among nine local grape cultivars in eastern Anatolia, which are slightly higher than those in our cultivars. Sabir et al. [39] reported glucose and fructose content in the ranges $8.64-10.70 \mathrm{~g} / 100 \mathrm{~g}$ and $8.04-9.41 \mathrm{~g} / 100 \mathrm{~g}$, respectively, among grape cultivars in Turkey. Rusjan and Korosec-Koruza [38] evaluated glucose and fructose content in grape berries in the ranges $5.09-8.99 \mathrm{~g} / 100 \mathrm{~g}$ and $5.48-8.39 \mathrm{~g} / 100 \mathrm{~g}$, respectively. Munoz-Robredo et al. [48] reported that three table grape cultivars ( $V$. vinifera L.) grown in Chile had fructose, glucose, and sucrose in the ranges $7.74-8.74 \mathrm{~g} / 100 \mathrm{~g}$, $8.03-8.70 \mathrm{~g} / 100 \mathrm{~g}$, and $0.73-0.90 \mathrm{~g} / 100 \mathrm{~g}$, respectively. Coelho et al. [44] reported fructose and glucose in the ranges $7.29-9.29 \mathrm{~g} / \mathrm{L}$ and $8.66-10.80 \mathrm{~g} / \mathrm{L}$, respectively, in juices of grape cultivars grown in Brazil. Our findings are related with the above reported results for glucose and fructose.

3.5. Total Carotenoids and Total Flavonoids. Table 6 shows total carotenoid and flavonoid contents of searched eight white and red grape cultivars and indicated statistically significant differences among them for both searched parameters at $p<0.05$ level.

Considering the carotenoid data, higher values were obtained for white skin colored cultivars compared to red ones. For Tokat cultivar, the highest value was determined $(18.60 \mu \mathrm{g} /$ g), followed by cv. Kutuk and Artvin, while the lowest value was observed in cv. Nanebur $(9.88 \mu \mathrm{g} / \mathrm{g})$, respectively (Table 6). There were few studies reporting total carotenoid content of white and red grapes. Derradj-Benmeziane et al. [45] reported total carotenoid content in Algerian grapes, where they detected values between 5.99 and $16.11 \mu \mathrm{g} / \mathrm{g}$. They also confirmed that white skin colored cultivars had higher total carotenoids content than red ones. As our experimental vineyard, climatic, soil, and cultivation conditions and treatments were similar to theirs, the differences among cultivars, therefore, could be explained by their genetic background. Giovanelli and Brenna 
TABLE 5: Vitamin C and sugars in berries of local grape cultivars.

\begin{tabular}{lcccc}
\hline Cultivar & Vitamin C $(\mathrm{mg} / 100 \mathrm{~g})$ & Glucose $(\mathrm{g} / 100 \mathrm{~g})$ & Fructose $(\mathrm{g} / 100 \mathrm{~g})$ & Sucrose $(\mathrm{g} / 100 \mathrm{~g})$ \\
\hline Artvin & $26.33 \pm 1.04 \mathrm{ab}$ & $7.10 \pm 0.19 \mathrm{e}$ & $5.82 \pm 0.10 \mathrm{~cd}$ & $0.83 \pm 0.03^{\mathrm{NS}}$ \\
Beyaz Istanbul & $20.60 \pm 0.93 \mathrm{c}$ & $9.35 \pm 0.23 \mathrm{~d}$ & $6.30 \pm 0.12 \mathrm{bc}$ & $0.95 \pm 0.04$ \\
Kirmizi Istanbul & $15.17 \pm 0.81 \mathrm{~d}$ & $11.10 \pm 0.25 \mathrm{c}$ & $8.44 \pm 0.12 \mathrm{a}$ & $0.55 \pm 0.02$ \\
Kara Turfanda & $25.02 \pm 1.14 \mathrm{~b}$ & $8.85 \pm 0.15 \mathrm{de}$ & $6.60 \pm 0.09 \mathrm{bc}$ & $0.74 \pm 0.03$ \\
Kutuk & $19.18 \pm 0.55 \mathrm{~cd}$ & $10.30 \pm 0.17 \mathrm{~cd}$ & $6.16 \pm 0.08 \mathrm{c}$ & $0.80 \pm 0.04$ \\
Nanebur & $30.18 \pm 0.1 .17 \mathrm{a}$ & $14.17 \pm 0.19 \mathrm{a}$ & $7.04 \pm 0.10 \mathrm{~b}$ & $0.47 \pm 0.00$ \\
Tokat & $22.45 \pm 0.88 \mathrm{ab}$ & $7.56 \pm 0.14 \mathrm{de}$ & $4.89 \pm 0.06 \mathrm{~d}$ & $0.64 \pm 0.01$ \\
Razaki & $27.44 \pm 0.94 \mathrm{ab}$ & $12.85 \pm 0.20 \mathrm{~b}$ & $7.10 \pm 0.11 \mathrm{~b}$ & $0.70 \pm 0.03$ \\
\hline
\end{tabular}

Different letters in the same column indicate statistically significant differences $(p<0.05)$.

TABLE 6: Total carotenoids, total flavonoids, and \% inhibition level of grape cultivars.

\begin{tabular}{lccc}
\hline Cultivar & Total carotenoid $(\mu \mathrm{g} / \mathrm{g} \mathrm{FW})$ & Total flavonoid $(\mathrm{mg}$ CE/g FW) & DPPH $(\%)$ \\
\hline Artvin & $16.33 \pm 0.31 \mathrm{c}$ & $0.61 \pm 0.03 \mathrm{de}$ & $64.45 \pm 1.45 \mathrm{e}$ \\
Beyaz Istanbul & $14.89 \pm 0.25 \mathrm{~d}$ & $0.53 \pm 0.03 \mathrm{de}$ & $66.70 \pm 1.65 \mathrm{de}$ \\
Kirmizi Istanbul & $12.14 \pm 0.16 \mathrm{e}$ & $0.88 \pm 0.02 \mathrm{c}$ & $72.14 \pm 1.80 \mathrm{c}$ \\
Kara Turfanda & $10.56 \pm 0.10 \mathrm{f}$ & $1.44 \pm 0.05 \mathrm{ab}$ & $78.83 \pm 2.13 \mathrm{~b}$ \\
Kutuk & $17.56 \pm 0.27 \mathrm{~b}$ & $0.66 \pm 0.02 \mathrm{~d}$ & $69.33 \pm 1.52 \mathrm{~cd}$ \\
Nanebur & $9.88 \pm 0.13 \mathrm{~g}$ & $1.56 \pm 0.06 \mathrm{a}$ & $81.46 \pm 2.37 \mathrm{a}$ \\
Tokat & $18.60 \pm 0.37 \mathrm{a}$ & $0.78 \pm 0.02 \mathrm{~cd}$ & $68.86 \pm 1.06 \mathrm{~d}$ \\
Razaki & $10.94 \pm 0.10 \mathrm{f}$ & $1.25 \pm 0.04 \mathrm{~b}$ & $76.30 \pm 1.10 \mathrm{bc}$ \\
\hline
\end{tabular}

Different letters in the same column indicate statistically significant differences $(p<0.05)$.

[49] determined among wine grape cultivars carotenoid concentration in the range of $1.1-9.1 \mu \mathrm{g} / \mathrm{g} \mathrm{dw}$ (dry weight). Kamffer et al. [50] found out that the amount of carotenoid is cultivar-dependent and could be influenced by climatic conditions, maturation stage, and used methods. Lee et al. [51] reported that soil with a low water holding capacity may have led to an increase in the carotenoid concentrations. In white grapes, chlorophylls and carotenoids play important roles in berry color and environmental interactions (e.g., radiative stresses). Generally, carotenoids have two main complementary and indispensable functions in the photosynthetic pathway of higher plants: light harvesting and photo-protection [52].

The total content of flavonoids for eight grape cultivars varied from $0.53 \mathrm{mg} \mathrm{CE} / \mathrm{g}$ to $1.56 \mathrm{mg} \mathrm{CE} / \mathrm{g}$ in the descending order: $\quad$ Nanebur $>$ Kara $\quad$ Turfanda $>$ Razaki $>$ Kirmizi Istanbul $>$ Tokat $>$ Kutuk $>$ Artvin $>$ Beyaz Istanbul. The red skin colored cultivars with blue-black and blue-dark red berry color (Nanebur, Kara Turfanda, Razaki) had higher flavonoid content than white ones (Table 6). In Algeria, Derradj-Benmeziane et al. [45] determined total flavonoids content from 0.40 to $1.09 \mathrm{mg} \mathrm{CE} / \mathrm{g}$, and similarly to our study, they also detected that red skin colored cultivars had higher total flavonoid content than white ones. Nile et al. [53] found total flavonoids content in grape cultivars grown in South Korea to be between 0.20 and $0.46 \mathrm{mg} / \mathrm{g}$ fw. They reported that high flavonoid content was related mainly to flavonol kaempferol. Bulgarian researchers [54] evaluated white and red grape cultivars with total flavonoids content between 0.37 and $0.77 \mathrm{mg} \mathrm{CE} / \mathrm{g}$, which indicate little lower values than those of our results. Mitic et al. [55] reported total flavonoids contents among seven grape cultivars in Serbia, which were in the range $0.60-1.46 \mathrm{mg} \mathrm{CE} / \mathrm{g}$, indicating good agreement with our results. The amount of flavonoids in grape berries is quite variable and influenced by genetic background of used material, collection period, climatic conditions, training systems, agricultural practices, berry parts, and used methods [53].

3.6. Percent Inhibition Level (Antioxidant Capacity). Percent inhibition level, the effect of free radical scavenging for all samples measured by DPPH test, is shown in Table 6 . The results indicate statistically important differences among used cultivars $(p<0.05)$.

$\%$ inhibition level of grape cultivars varied from $64.45 \%$ to $81.46 \%$ in this ascending order: Artvin $>$ Beyaz Istanbul $>$ Tokat $>$ Kutuk $>$ Kirmizi Istanbul $>$ Razaki $>$ Kara Turfanda $>$ Nanebur. These results correspond to the results of flavonoid contents. Furthermore, it was observed that the berries with darker color (blue-black), specifically Kara Turfanda and Nanebur, had higher free radical scavenging ability than brighter ones.

Nile et al. [53] reported a wide variation of results for free radical scavenging ability among grape cultivars belonging to V. vinifera, V. labrusca, and V. hybrid, between $35.4 \%$ and $84.5 \%$. According to previously published results, the antioxidant activity of grapes is caused mainly by phenolics, particularly flavonoids $[45,53]$. The results presented here thus provide valuable data of total flavonoid content, and \% inhibition level of several locally important grape cultivars.

\section{Conclusion}

In the present study, some important morphological traits and biochemical characteristics of eight local grape cultivars grown in Coruh valley in Turkey were determined. The study revealed considerable genetic diversity observed for both morphological traits and biochemical components due to 
complex background of cultivars, indicating that local grape cultivars are valuable plant material. It was observed that the berries with darker skin color (blue-black), specifically Kara Turfanda and Nanebur, had higher free radical scavenging ability than the brighter (green-yellow) ones, which correspond also to the results of flavonoid contents. The biochemical markers were able to differentiate between local grape cultivars, and the information obtained here will be useful for collection, conservation, and usage in various grape breeding programs.

\section{Data Availability}

The data are available from the author Sezai Ercisli upon request (sercisli@gmail.com).

\section{Conflicts of Interest}

The authors declare that they have no conflicts of interest.

\section{Acknowledgments}

The financial support was provided by Tomas Bata University in Zlin, Faculty of Technology (IGA FT 2021/008).

\section{References}

[1] S. Serçe, M. Özgen, A. A. Torun, and S. Ercişli, "Chemical composition, antioxidant activities and total phenolic content of Arbutus andrachne L. (Fam. Ericaceae) (the Greek strawberry tree) fruits from Turkey," Journal of Food Composition and Analysis, vol. 23, no. 6, pp. 619-623, 2010.

[2] H. Dogan, S. Ercisli, E. Temim et al., "Diversity of chemical content and biological activity in flower buds of a wide number of wild grown caper (Capparis ovate Desf.) genotypes from Turkey," Comptes Rendus De L Academie Bulgare Des Sciences, vol. 67, no. 11, pp. 1593-1600, 2014.

[3] S. P. Eyduran, M. Akin, S. Ercisli, E. Eyduran, and D. Maghradze, "Sugars, organic acids, and phenolic compounds of ancient grape cultivars (Vitis vinifera L.) from Igdir province of Eastern Turkey," Biological Research, vol. 48, no. 1, p. 2, 2015.

[4] M. K. Gecer, T. Kan, M. Gundogdu, S. Ercisli, G. Ilhan, and H. I. Sagbas, "Physicochemical characteristics of wild and cultivated apricots (Prunus armeniaca L.) from Aras valley in Turkey," Genetic Resources and Crop Evolution, vol. 67, no. 4, pp. 935-945, 2020.

[5] P. E. Read and S. Gu, "A century of American viticulture," HortScience, vol. 38, no. 5, pp. 943-951, 2003.

[6] W. C. Olien, "The muscadine grape: botany, viticulture, history, and current industry," HortScience, vol. 25, no. 7, pp. 732-739, 1990.

[7] D. N. Kuria, A. B. Nyende, and F. K. Rimberia, "Evaluation of morphological and quality characteristics of introduced grape cultivars produced under greenhouse conditions in Kenya," African Journal of Agricultural Research, vol. 15, no. 2, pp. 269-277, 2020.

[8] B. L. Comeaux, W. B. Nesbitt, and P. R. Fantz, "Taxonomy of the native grapes of North Carolina," Castanea, vol. 52, no. 3, pp. 197-215, 1987.

[9] A. Ibacache, F. Albornoz, and A. Zurita-Silva, "Yield responses in Flame seedless, Thompson seedless and Red Globe table grape cultivars are differentially modified by rootstocks under semi arid conditions," Scientia Horticulturae, vol. 204, no. 6, pp. 25-32, 2016.

[10] G. Soylemezoglu, Y. S. Agaoglu, and I. Uzun, "Ampelographic characteristics and isozymic analysis of Vitis vinifera spp. sylvestris (Gmel.) in Southwestern Turkey," Biotechnology \& Biotechnological Equipment, vol. 15, no. 2, pp. 106-113, 2014.

[11] B. Isci and A. Altindisli, "Ampelographic characterization of Turkish indigenous grape accessions and European cultivars (Vitis vinifera L.)," International Journal of Agriculture Environment and Food Sciences, vol. 1, no. 1, pp. 1-16, 2017.

[12] S. Tangolar, S. Eymirli, G. Ozdemir, H. Bilir, and S. G. Tangolar, "Determine phonological, bunch and berry characteristics of some grape cultivars grown in Pozanti, Adana," in Proceedings of the 5th National Viticulture and Enology Symposium, pp. 372-380, Portland, OR, USA, June 2002.

[13] A. Sabir, Ampelographic and molecular characterization of some grape cultivars and rootstocks, Ph.D. Thesis, Cukurova University, Adana, Turkey, 2008.

[14] F. Emanuelli, S. Lorenzi, L. Grzeskowiak et al., "Genetic diversity and population structure assessed by SSR and SNP markers in a large germplasm collection of grape," BMC Plant Biology, vol. 13, no. 39, pp. 39-17, 2013.

[15] M. Lamine, H. Zemni, S. Ziadi et al., "Multivariate analysis and clustering reveal high morphological diversity in Tunisian autochthonous grapes (Vitis vinifera): insights into characterization, conservation and commercialization," OENO One, vol. 48, no. 2, pp. 111-122, 2014.

[16] S. Khalil, J. Tello, F. Hamed, and A. Forneck, “A multivariate approach for the ampelographic discrimination of grapevine (Vitis vinifera) cultivars: application to local Syrian genetic resources," Genetic Resources and Crop Evolution, vol. 64, no. 5, pp. 1841-1851, 2017.

[17] D. Vauzour, A. Rodriguez-Mateos, G. Corona, M. J. OrunaConcha, and J. P. E. Spencer, "Polyphenols and human health: prevention of disease and mechanisms of action," Nutrients, vol. 2, no. 11, pp. 1106-1131, 2010.

[18] R. Krikorian, E. L. Boespflug, D. E. Fleck et al., "Concord grape juice supplementation and neurocognitive function in human aging," Journal of Agricultural and Food Chemistry, vol. 60, no. 23, pp. 5736-5742, 2012.

[19] K. Ali, F. Maltese, Y. H. Choi, and R. Verpoorte, "Metabolic constituents of grapevine and grape-derived products," Phytochemistry Reviews, vol. 9, no. 3, pp. 357-378, 2010.

[20] F. Ates, H. Coban, Z. Kara, and A. Sabir, "Ampelographic characterization of some grape cultivars (Vitis vinifera L.) grown in south-western region of Turkey," Bulgarian Journal of Agricultural Science, vol. 17, no. 3, pp. 314-324, 2011.

[21] H. Doulati-Baneh, S. A. Mohammadi, and M. Labra, "Genetic structure and diversity analysis in Vitis vinifera L. cultivars from Iran using SSR markers," Scientia Horticulturae, vol. 160, no. 12, pp. 29-36, 2013.

[22] V. Salimov, A. Shukurov, and R. Asadullayev, "Study of diversity of Azerbaijan local grape varieties basing on OIV ampelographic descriptors," Annals of Agrarian Science, vol. 15, no. 3, pp. 386-395, 2017.

[23] N. Gokturk Baydar, "Organic acid, tocopherol, and phenolic compositions of some Turkish grape cultivars," Chemistry of Natural Compounds, vol. 42, no. 2, pp. 156-159, 2006.

[24] R. G. Somkuwar, P. B. Taware, M. A. Bhange, J. Sharma, and I. Khan, "Influence of different rootstocks on growth, photosynthesis, biochemical composition, and nutrient contents in 'fantasy seedless' grapes," International Journal of Fruit Science, vol. 15, no. 3, pp. 251-266, 2015. 
[25] M. A. Rodriguez-Delgado, S. Malovana, J. P. Perez, T. Borges, and F. J. Garcia-Montelongo, "Separation of phenolic compounds by high-performance liquid chromatography with absorbance and fluorimetric detection," Journal of Chromatography A, vol. 912, no. 2, pp. 249-257, 2001.

[26] H. K. Sasmaz, T. Uzlasir, and H. Kelebek, "Effect of infusion time on the phenolic profile and some physicochemical properties of Lavandula x intermedia cv. "SUPER", Journal of Raw Materials to Processed Foods, vol. 1, no. 2, pp. 55-71, 2020.

[27] A. E. Bevilacqua and A. N. Califano, "Determination of organic acids in dairy products by high performance liquid chromatography," Journal of Food Science, vol. 54, no. 4, p. 1076, 1989.

[28] P. Melgarejo, D. M. Salazar, and F. Artés, "Organic acids and sugars composition of harvested pomegranate fruits," European Food Research and Technology, vol. 211, no. 3, pp. 185-190, 2000.

[29] B. Cemeroglu, Food Analysis, Food Technology Association Publication, Ankara, Turkey, 2007.

[30] A. Sass-Kiss, J. Kiss, P. Milotay, M. M. Kerek, and M. TothMarkus, "Differences in anthocyanin and carotenoid content of fruits and vegetables," Food Research International, vol. 38, no. 8, pp. 1023-1029, 2005.

[31] D.-O. Kim, S. W. Jeong, and C. Y. Lee, "Antioxidant capacity of phenolic phytochemicals from various cultivars of plums," Food Chemistry, vol. 81, no. 3, pp. 321-326, 2003.

[32] M. Anastasiadi, H. Pratsinis, D. Kletsas, A.-L. Skaltsounis, and S. A. Haroutounian, "Bioactive non-coloured polyphenols content of grapes, wines and vinification by-products: evaluation of the antioxidant activities of their extracts," Food Research International, vol. 43, no. 3, pp. 805-813, 2010.

[33] Z. Liang, B. Wu, P. Fan et al., "Anthocyanin composition and content in grape berry skin in Vitis germplasm," Food Chemistry, vol. 111, no. 4, pp. 837-844, 2008.

[34] J. Mulero, F. Pardo, and P. Zafrilla, "Antioxidant activity and phenolic composition of organic and conventional grapes and wines," Journal of Food Composition and Analysis, vol. 23, no. 6, pp. 569-574, 2010.

[35] A. Mota, J. Pinto, I. Fartouce et al., "Chemical profile and antioxidant potential of four table grape (Vitis vinifera) cultivars grown in Douro Region, Portugal," Ciência e Técnica Vitivinícola, vol. 33, no. 2, pp. 125-135, 2018.

[36] R. S. Jackson, "Chemical constituents of grapes and wine," in Wine Science, R. S. Jackson, Ed., pp. 232-280, Academic Press, St. Catherines, On, USA, 2nd edition, 2000.

[37] C. Conde, P. Silva, N. Fontes et al., "Biochemical changes throughout grape berry development and fruit and wine quality," Food, vol. 1, no. 1, pp. 1-22, 2007.

[38] D. Rusjan and Z. Korosec-Koruza, "Morphometrical and biochemical characteristics of red grape varieties (Vitis vinifera L.) from collection vineyard," Acta Agriculturae Slovenica, vol. 89, no. 1, pp. 245-257, 2007.

[39] A. Sabir, E. Kafkas, and S. Tangolar, "Distribution of major sugars, acids, and total phenols in juice of five grapevine (Vitis spp.) cultivars at different stages of berry development," Spanish Journal of Agricultural Research, vol. 8, no. 2, pp. 425-433, 2010.

[40] C. Bing, Z. Jing-Fang, X. Hong-Yu et al., "Analysis of organic acid contents in wine grape from different cultivars," Food Science, vol. 34, no. 12, pp. 223-228, 2013.

[41] A. Güler and A. Candemir, "Determination of physicochemical characteristics, organic acid and sugar profiles of Turkish grape juices," International Journal of Agriculture,
Environment and Food Sciences, vol. 4, no. 2, pp. 149-156, 2020.

[42] Y. Soyer, N. Koca, and F. Karadeniz, "Organic acid profile of Turkish white grapes and grape juices," Journal of Food Composition and Analysis, vol. 16, no. 5, pp. 629-636, 2003.

[43] M. D. S. Lima, I. D. S. V. Silani, I. M. Toaldo et al., "Phenolic compounds, organic acids and antioxidant activity of grape juices produced from new Brazilian varieties planted in the Northeast Region of Brazil," Food Chemistry, vol. 161, no. 14, pp. 94-103, 2014.

[44] E. M. Coelho, C. V. Da Silva Padilha, G. A. Miskinis et al., "Simultaneous analysis of sugars and organic acids in wine and grape juices by HPLC: method validation and characterization of products from northeast Brazil," Journal of Food Composition and Analysis, vol. 66, no. 3, pp. 160-167, 2018.

[45] F. Derradji-Benmeziane, R. Djamai, and Y. Cadot, "Antioxidant capacity, total phenolic, carotenoid, and vitamin $\mathrm{C}$ contents of five table grape varieties from Algeria and their correlations," Journal International des Sciences de la Vigne et $d u$ Vin, vol. 48, no. 32, pp. 153-162, 2014.

[46] H. Dou, S. Jones, T. Obrea, and B. Rouse, "Influence of various phosphorus and potassium rates on juice vitamin $c, \beta$-carotene, lycopene and sugar concentrations of flame grapefruit," Proceedings of the Florida State Horticultural Society, vol. 118, no. 3, pp. 372-375, 2005.

[47] S. K. Lee and A. A. Kader, "Preharvest and postharvest factors influencing vitamin C content of horticultural crops," Postharvest Biology and Technology, vol. 20, no. 4, pp. 207-220, 2000.

[48] P. Muñoz-Robredo, P. Robledo, D. Manríquez, R. Molina, and B. G. Defilippi, "Characterization of sugars and organic acids in commercial varieties of table grapes," Chilean Journal of Agricultural Research, vol. 71, no. 3, pp. 452-458, 2011.

[49] G. Giovanelli and O. Brenna, "Evolution of some phenolic components, carotenoids and chlorophylls during ripening of three Italian grape varieties," European Food Research and Technology, vol. 225, no. 2, pp. 145-150, 2007.

[50] Z. Kamffer, K. A. Bindon, and A. Oberholster, "Optimization of a method for the extraction and quantification of carotenoids and chlorophylls during ripening in grape berries (Vitis vinifera cv. Merlot)," Journal of Agricultural and Food Chemistry, vol. 58, no. 11, pp. 6578-6586, 2010.

[51] S. H. Lee, M. J. Seo, M. Riu et al., "Vine microclimate and norisoprenoid concentration in Cabernet Sauvignon grapes and wines," American Journal of Enology and Viticulture, vol. 58, no. 3, pp. 291-301, 2007.

[52] K. E. Palett and A. J. Young, "Carotenoids," in Antioxidants in Higher Plants, R. G. Alscher and J. L. Hess, Eds., pp. 60-89, CRC Press, Boca Raton, FL, USA, 1993.

[53] S. H. Nile, S. H. Kim, E. Y. Ko, and S. W. Park, "Polypenolic contents and antioxidant properties of different grape (V. vinifera, V. labrusca and V. hybrid) cultivars," BioMed Research International, vol. 2013, Article ID 718065, 5 pages, 2013.

[54] D. Marinova, F. Ribarova, and M. Atanassova, "Total phenolics and total flavonoids in Bulgarian fruits and vegetables," Journal of the University of Chemical Technology and Metallurgy, vol. 40, no. 3, pp. 255-260, 2005.

[55] M. Mitic, J. M. Souquet, M. V. Obradovic, and S. S. Mitic, "Phytochemical profiles and antioxidant activities of Serbian table and wine grapes," Food Science and Biotechnology, vol. 21, no. 6, pp. 1619-1626, 2012. 